NBER WORKING PAPER SERIES

\title{
COMMERCIALIZING KNOWLEDGE: UNIVERSITY SCIENCE, KNOWLEDGE CAPTURE, AND FIRM PERFORMANCE IN BIOTECHNOLOGY
}

\author{
Lynne G. Zucker \\ Michael R. Darby \\ Jeff S. Armstrong \\ Working Paper 8499 \\ http://www.nber.org/papers/w8499 \\ NATIONAL BUREAU OF ECONOMIC RESEARCH \\ 1050 Massachusetts Avenue \\ Cambridge, MA 02138 \\ October 2001
}

\begin{abstract}
This research has been supported by grants from the University of California's Industry-University Cooperative Research Program, the University of California Systemwide Biotechnology Research and Education Program, the Alfred P. Sloan Foundation through the NBER Research Program on Industrial Technology and Productivity, and the National Science Foundation (SES 9012925). We also appreciate very useful comments from Scott Shane, Scott Stern, and other participants in the Conference on Technology Transfer and University Entrepreneurship, Georgia Institute of Technology, Atlanta, Georgia, December 7-9,2000. We are also indebted to a remarkably talented team of post-doctoral fellows and research assistants who have built the Zucker-Darby relational database over the last decade, and especially to Dr. David Waguespack who prepared the series on all publishing between firms and the top 112 research universities for biotechnology firms based on ISI data. This paper is a part of the NBER's research program in Productivity.The views expressed herein are those of the authors and not necessarily those of the National Bureau of Economic Research.
\end{abstract}

(C) 2001 by Lynne G. Zucker, Michael R. Darby and Jeff S. Armstrong. All rights reserved. Short sections of text, not to exceed two paragraphs, may be quoted without explicit permission provided that full credit, including $(\subset$ notice, is given to the source. 
Commercializing Knowledge: University Science, Knowledge Capture, and Firm Performance in Biotechnology

Lynne G. Zucker, Michael R. Darby and Jeff S. Armstrong

NBER Working Paper No. 8499

October 2001

JEL No. O31, L14, L65, O32

\begin{abstract}
$\underline{\text { ABSTRACT }}$
Commercializing knowledge involves transfer from discovering scientists to those who will develop it commercially. New codes and formulae describing discoveries develop slowly - with little incentive if value is low and many competing opportunities if high. Hence new knowledge remains naturally excludable and appropriable. Team production allows more knowledge capture of tacit, complex discoveries by firm scientists. A robust indicator of a firm's tacit knowledge capture (and strong predictor of its success) is the number of research articles written jointly by firm scientists and discovering, "star" scientists, nearly all working at top universities. An operationally attractive generalization of our star measure - collaborative research articles between firm scientists and top research university scientists - replicates the impact on firm success. In panel analyses, publications by firm scientists with stars and/or top-112 university scientists increase the number and citation rate for firm patents. Further, star articles increase these rates significantly more than other top-112 university scientists' articles. Cross-sectional analyses of products and employment show a similar pattern of positive effects on firms' success of collaborations with stars or top university scientists, but estimates of differential effects are non-robust due to multicollinearity. Venture capital funding has significant, usually positive effects on firm success.
\end{abstract}

Lynne G. Zucker

Professor of Sociology \&

Director, Center for International Science,

Technology, and Cultural Policy, SPPSR

University of California, Los Angeles

Los Angeles, CA 90095-1551

and NBER

zucker@ucla.edu

Jeff S. Armstrong

Economist

Analysis Group/Economics

The Chrysler Building

405 Lexington Avenue, $47^{\text {th }}$ Floor

New York, NY 10174

jarmstrong@analysisgroup.com
Michael R. Darby

Cordner Professor of Money \& Financial Markets

Anderson Graduate School of Management

University of California, Los Angeles

Los Angeles, CA 90095-1551

and NBER

darby@ucla.edu 


\section{Commercializing Knowledge: University Science, Knowledge Capture, and Firm Performance in Biotechnology}

by Lynne G. Zucker, Michael R. Darby, and Jeff S. Armstrong

\section{Introduction}

Our research program over the past ten years has focused on the use of basic science knowledge in commercial firms and the impact of that knowledge on firm performance. In our earlier research, we have found substantial consistent evidence that top academic science, specifically the star scientists who make most of the defining discoveries, provides intellectual human capital that defines the technology of the firm-at least following scientific breakthroughs. Though there are likely to be considerable spillover effects when knowledge is created or employed (Jaffe 1986;1989), and perhaps also an important symbolic and legitimating function of high quality science for commercial activity (Stephan and Everhart 1998), our empirical work identifies the main and robust empirical effects due to real scientific labor contributions of star scientists to performance of the firm.

To "detect" stars and quantify their labor contributions to firms, we identified 327 "star" bio-scientists worldwide based on their publications of genetic-sequence discovery articles up to early 1990 before gene-sequencing machines were in widespread use. Stars were those cumulatively reporting more than 40 genetic-sequence discoveries or on 20 or more articles reporting any genetic-sequence discoveries in GenBank (1990). We identified every "star" article on which the star, or (more frequently) a co-author, was affiliated with a firm. The numbers of these articles was our measure of the depth of star involvement in the firm.

Before turning to new results reported in this paper, a brief summary of our prior results will be useful for readers not already familiar with our work: 
- Location of top, "star" scientists predicts location of firm entry into new technologies (both new and existing firms), shown for the U.S. and Japan in biotechnology (Zucker, Darby, and Brewer 1998, Darby and Zucker 2001) and replicated for the semiconductor industry in the U.S. (Torero, Darby, and Zucker 2001).

- Ties that involve actual work at the science bench between star scientists (mostly academics) and firm scientists consistently have a significant positive effect on a wide range of firm performance measures in biotechnology (Zucker, Darby, and Armstrong 1998; Zucker and Darby 2001) and in semiconductors for number and quality of patents (Torero 1998). Ties to stars also shorten the time to IPO (firms are younger) and increase the amount of IPO proceeds (Darby, Zucker, and Welch 2001).

- As the quality of an academic star bio-scientist increases and his/her research becomes more relevant to commercialization, the probability increases that the scientist conducts joint research or moves to a firm. As expected scientific returns increase - measured by citations to other local star scientists working with firms - the probability that the next star will begin working with a firm also increases (Zucker, Darby, and Torero 2001). Quality is also positively related to working with firms in Japan, but only number of articles predicts significantly with this smaller sample (Zucker, Darby, and Torero 2000).

Our findings on the importance of basic university science to successful commercialization of important scientific discoveries are confirmed in other research, especially the importance of intellectual human capital (Di Gregorio and Shane 2000). Faculty are a key resource in creating and transferring early, discovery research via commercial entrepreneurial behavior (Yarkin 2000). Jensen and Thursby (2001) confirm that active, self-interested 
participation of discovering professors is an essential condition for successful commercial licensing of university inventions. Thursby and Thursby (2000) find that the sharp increase in university-industry technology transfer has not resulted so much from a shift in the nature of faculty research as from an increased willingness of faculty and administrators to license and increased interest on the part of firms.

In this paper, we continue our research program on the economic value of knowledge, especially tacit knowledge at the time of commercially relevant scientific breakthroughs. We compare the real effects on the performance of biotech firms of two overlapping groups of academic scientists who collaborate with firm scientists: the stars who made significantly more genetic sequence discoveries, and all relevant scientists (including the bulk of the stars) employed at one of the top 112 U.S. research universities ranked by federal research funding. Our overall results again support the strong effects of academic science on the success of firms. Both science measures have strong positive independent effects on most performance measures. The patent panels show that the labor effort of the stars has a significant incremental impact on firm performance above and beyond the effects of all scientists from top research universities working with the firm. In cross-section estimates, we find significant positive effects from either star or top-112 faculty linkages but efforts to enter both sets of variables in the same regressions are confounded by multicollinearity. We conclude that affordable bibliometric measures are good but not perfect substitutes for the costly-to-construct star measures.

The paper is organized as follows. In Section 2 we develop our theoretical approach to: (a) the sources and implications of the information advantage - common to most scientific breakthrough knowledge - held by the discovering scientists, (b) the difficulties inherent to the transfer of tacit knowledge that lead to joint research, and (c) the amount of knowledge capture 
necessary for firm to offset sunk commercial development costs. In Section 3 we sketch the history of scientific development and rise of the biotech industry, focusing on the ties between academic science and commercial firms. Since data are the plural of anecdote, we present qualitative evidence of the importance of ties to star scientists for the performance of the most successful firms. In Section 4 we briefly review the variables and their sources and then present and discuss the empirical results. We estimate poisson regressions (and linear-least squares for employment) that explain the performance of a panel of biotech firms for patents and citationweighted patents, and cross-sections for products in development, on the market, and employment. In these regressions, we systematically test the predictive power of science (stars and top-112 university scientists tied to the firm via co-authoring of scientific research, as well as all local academic scientific publishing by stars), venture capital, and other firm characteristics such as use of the dominant technology (rDNA or genetic engineering). In Section 5 we offer our conclusions. Detail on the data set and supplementary analyses are compiled in a separate appendix which is cross-referenced below and available from the authors on request. 


\section{The Real Effects of Knowledge Capture}

Academic to industry technology transfers may be rare, but we believe they can still account for the bulk of technological progress. These are not pure "transfers," but necessarily knowledge captures to the degree necessary to offset sunk development, marketing, and other costs invested in moving a discovery into a commercial innovation. Many fundamental industry transformations or technological breakthroughs can be traced to specific advances in science. While the industries experiencing technological discontinuity are a distinct minority in our economy, we argue that a distinct minority of firms within this distinct minority of industries account for a large part of the aggregate technological progress conventionally measured in productivity studies (Harberger 1998, Darby and Zucker 2002).

\section{Knowledge and the Market for Information}

Our argument starts from the classic Stigler (1961) observation that information is a valuable and costly resource and that individuals are thus motivated to adopt strategies such as search that weighs the expected costs and benefits of acquiring information. For example, if individuals' search involves unique goods, then costs of search are sufficiently high that transactions are commonly localized as a device for identifying potential buyers and sellers. Stigler pointed out that medieval markets were an example of actual localization; advertising is an example of a "virtually" localized market.

We argue that another mechanism of "virtual" localization is a profession, or more commonly, a sub-specialty within a profession. ${ }^{1}$ Here, the buyers and sellers of knowledge, including new or "breakthrough" discoveries, are brought together in a highly balkanized market in which the participants share a reasonably similar endowed knowledge base that makes the new 
knowledge potentially understandable and useable. The size and geographic distribution of that knowledge base determines the extent of initial demand for the new knowledge. For the purposes of our argument here, information and knowledge are equivalent.

\section{From Tacit to Codified Knowledge}

New information tends to be produced in tacit form, increasing in tacitness as a function of distance from prior knowledge (hence, especially breakthrough knowledge), and requires resources to codify. Tacit knowledge tends to be highly personal, initially known only by one person (or a small team of discovering scientists) and is difficult to transfer to others (Polyani 1962 and Schutz 1962).

As knowledge increases in complexity, the probability increases that deviation from "textbook" description of action will be required (Nelson 1959 and Nelson and Winter 1982). For example, internal bleeding during surgery requires decisions about whether and how to deviate from the textbook that cannot be fully prescribed in advance. This kind of complexity leads to knowledge remaining tacit longer, perhaps remaining an "active task" that changes its nature in response to contingencies in contrast to an "inert task" such as a secretary typing a letter written by his/her boss (Scott et al. 1967).

Knowledge becomes shared (inter-subjective) to the extent that codes or formulas are borrowed from pre-existing knowledge and/or are newly created. Relevance to earlier knowledge allows borrowing of codes, mathematical expressions and relations, and even machines that "embody" those codes/math. Such knowledge is cumulative and can be easily understood and transferred, relying on references to the well-understood prior scientific literature. 
But new knowledge that cannot be readily grafted on to old is likely to offer more opportunities. Opportunity can shift incentives - increasing them along a continuum from incremental change to breakthrough discoveries (Klevorick et al. 1995). Increased incentives to enter arise from these greater opportunities.

Discovering scientists become important in technology transfer when a new discovery has both high commercial value and a combination of scarcity and tacitness that defines natural excludability, the degree to which there is a barrier to the flow of the valuable knowledge from the discoverers to other scientists. Tacit, complex knowledge provides partial natural protection of information, both separately and jointly with more formal property rights. Those with the most information about breakthrough discoveries are the scientists actually making them, so there is initial natural scarcity. To the extent that the knowledge is both scarce and tacit, it constitutes intellectual human capital retained by the discovering scientists and therefore they become the main resource around which firms are built or transformed (Zucker, Darby, and Brewer 1998, Zucker, Darby, and Armstrong 1998). Hence, tacit knowledge can be viewed as at least partially rivalrous and excludable information and thus "appropriable" as long as it remains difficult (or impossible) to learn it.

As tacit knowledge becomes increasingly codified—or translated into "recipe knowledge" as Schutz (1962) terms it - tacitness decreases and knowledge transfer is easier. But significant barriers stand in the way of codification. Relevance between old and new knowledge can be difficult to determine (Schutz 1970), increasing the demand for social construction of new codes, formulae, and machines. The greater the discontinuity, the more difficult it is to anchor in prior systems of knowledge. 
Until there is a reliable indicator of the value of the new knowledge, the size of the market for codification is unlikely to be large enough to cover the cost of developing the new codes. Paradoxically, once the value is known:

- If the value is low relative to alternative uses of scientific talent, then there are few incentives to codify it.

- If it is high, those few scientists who hold the new knowledge will have to weigh returns to codification against returns to time invested in scientific research, a tradeoff that pits knowledge transfer against knowledge creation.

- Hence, the average scientific discovery is never codified, and valuable discoveries experience a significant codification lag that tends to increase with their value.

\section{Knowledge Capture via Team Production}

Knowledge that is cumulative builds on an existing set of words and symbols, and hence involves less or no barrier to communication: Listening to a lecture or reading a text can suffice. But tacit knowledge often requires that one of those already holding that knowledge work with the novices to teach them in a hands-on process. For example, $81 \%$ of the new authors enter GenBank by writing with old authors, and new authors write exclusively with new authors a significant 36 percent less than "old," experienced authors write exclusively with other "old" authors after excluding all sole authored papers (Zucker, Darby and Torero 2001). Transfer may be very effective - there are well-documented effects of cumulative experience on performance improvement (Pisano et. al 2001) - but it is slow and requires the active participation of the holder of the tacit knowledge. 
Discovering scientists are typically willing to transfer knowledge primarily in the context of their on-going laboratory work. At the extreme, when tacitness is high, it is their collaborators on their research team who are the recipients of this knowledge; others are excluded through lack of access. Thus, the initial cost of entry is high. But entry cost tends to decline over time, and the probability of an error in the initial discovery also declines as others replicate it, thus reducing risk to the new entering scientist. ${ }^{2}$

This restricted process of transfer will more often than "normal science" lead to sufficient knowledge capture to justify the cost of commercial development by a firm. Knowledge capture explains why tacit knowledge tends to be highly localized: it will be concentrated geographically around where the discoveries are made (or where the discoverers move). As shown in Figure 1, there is considerable concentration of patented inventions, as well as human therapies and vaccines in development and on the market. Just two states, California and Massachusetts with $14 \%$ of the U.S. population, have a disproportionate share especially of U.S. products in development (49\%) and on the market (58\%). Patenting is somewhat less concentrated; since patenting is both an input and an output of the innovation process, this may suggest a lessening of geographic concentration, perhaps as the discoveries mature and are codified. Generally patents provide a useful incentive to the codification of knowledge, but in the case of patented cell lines a novel technique - deposit in an approved depositary to be publicly available upon patent expiration - acknowledged the difficulty in codifying exactly how the new organisms could be created.

Understanding the role of scientific teams in tacit knowledge transfer extends the arguments for team production: (a) Team organization makes routine the transfer of tacit knowledge from the discoverer to other team members, and if team members cross 
organizational boundaries then tacit knowledge is efficiently transferred - in the present case, most interestingly from university discovering scientists to firm scientists (Zucker, Darby and Armstrong 1998). (b) Through team organization, more productive cooperation is often achieved via specialization than possible through the linking of individual efforts across impersonal markets (Demsetz 1995: p. 17).

The greater the labor effort of the discovering university scientist(s) with teams containing firm scientists, the greater the amount of tacit knowledge transfer. In bench level collaboration, you can actually see how the science is done. As tacit knowledge transfer increases from the discovering scientists, the success of the firm also increases. Thus, managers of high tech firms have incentives to hire the top-discovering scientists if their discoveries have commercial value. Discovering scientists also have incentives to found a new firm. In sharp contrast, in industries where "normal science" reigns, hiring of below average, acceptably competent scientists at a low wage is the typical practice (Kornhauser 1962). Obviously, each can be a market-value-maximizing strategy for the firms facing different knowledge frontiers. 


\section{Scientists' Leadership and Industry Success: Commercializing Knowledge}

Biotechnology is a preeminent example of an industry undergoing very rapid growth associated with radical technological change initiated in academe and based on basic science breakthroughs. The key attributes can be summarized concisely:

- Breakthrough discovery: Professors Stanley Cohen (Stanford) and Herbert Boyer (University of California-San Francisco) reported the basic technique for recombinant DNA, also known as rDNA, genetic engineering, or gene splicing (Cohen, Chang, Boyer, and Helling 1973).

- University scientists: We identified star bio-scientists based on genetic sequence discoveries reported in GenBank (1990), an on-line reference file, and in this paper introduce bio-scientists identified in ISI's electronic file of research articles written by at least one author located at one of the top-112 U.S. research universities. ${ }^{3}$ Star articles are (nearly) a subset of top-112 articles (U.S. stars not in a top-112 university and conference papers - less than $1 \%$ of the total star articles - are not included in the ISI article files.)

- Links/collaborations with firms: Articles that are co-authored by firm employees and top scientists, including "stars" and the top-112 university scientists indicate the intensity of involvement with the firm's research effort. ${ }^{4}$ Most of these scientists "wear two hats," one as professor at a university and one as a leader or lab head at a firm; confirmed through interviews at universities and firms on both coasts. 


\section{Firm Success and Knowledge Capture}

The degree to which an open scientific literature can produce such strong apparent "knowledge capture" effects on firm success rests on: (a) Characteristics of tacit, complex knowledge that lead to natural excludability; and (b) Selection by firms of discoveries for which the degree of knowledge capture is likely to offset sunk costs incurred in making the scientific discovery a commercial innovation.

To provide some intuition for our regression results, we first briefly review examples of the prominent positions that top academic scientists are given in the most successful biotech firms, identify their co-publishing with the firm, and finally explore the impact that top scientists' co-publications with firm scientists have on success.

\section{Top 10 Biotech Firms}

Individual scientists are often highlighted in an IPO prospectus. ${ }^{5}$ These scientists typically achieved prominence in both their university and private sector appointments. Examples of distinguished academics from the top-112 universities ${ }^{6}$ that were appointed to corporate officer positions in one of the top 10 biotechnology firms (as of 1994) include: (a)

Herbert Boyer to the position of Vice President and Director of Genentech Inc; ${ }^{7}$ (b) Edward Penhoet, former faculty member of the Biochemistry Department at UC-Berkeley and cofounder of Chiron, to the position of President, CEO, and Director of Chiron; (c) Walter Gilbert, the American Cancer Society Professor of Molecular Biology at Harvard University and 1980 Noble prize winner, to several of Biogen's boards, with Phillip Sharp, Professor of Biology at MIT, and Daniel Wang, Professor of Chemical and Biochemical Engineering at MIT, on its Scientific Board; (d) Two founders of Genetics Institute were university faculty, who also were 
executive officers and directors of the company, as well as members of its Scientific Advisory Board; and (e) Amgen included on its Scientific Board prominent university professors from UCLA, CalTech, and Stanford, all members of the National Academy of Sciences.

Table 1 shows that 40 percent of these top- 10 biotech companies reported at least one star on their team when going public, while 70 percent had linked articles (star co-publishing with at least one firm employee). Not surprisingly, because of the much broader coverage of both scientists and universities, these top-10 biotech companies reported a higher percentage of top112 university scientists: 80 percent reported at least one top-112 scientist on their team when going public, and 90 percent had core collaborations with one or more of these scientists. The advantage of the publishing measure is that it weights the amount of involvement of the scientist: for example, Centocor had only 1/20 as many core collaborative research articles as Genentech.

IPOs listed many former or current university professors as company founders, officers, directors or key members of scientific advisory boards (see Appendix Table A1). Almost every scientist holding a top management position had done so since the company's founding. These scientists were not brought in as part of the preparation for the IPO to merely "signal" the firm's success, contrary to a suggestion in Stephan and Everhart (1998).

\section{Is Success in the Stars?}

Certainly, scientists in high-ranking positions in these now public firms provide scientific control and are important for firm success. However, the majority of firms in our sample do not go public before the end of our time period. In any case, we are interested in the actual work that top scientists do that is joint with the firm. We measure this joint work by the cumulative number of collaborative articles. 
Using the total number of joint articles, drawing on both of our science measures, we can take a preliminary look at our findings by graphing the mean values of the cumulative number of tied articles: for the stars, articles that involve a star scientist and a firm scientist (where the star can also be an employee of the firm) and for scientists at the top-112 universities, articles that involve joint work by at least one university and one firm scientist. These values are shown in Figure 2a. The differences are particularly striking at the $10+$ article level. The mean success by tied star articles is consistently and markedly higher than for top-112 university scientists across our major success measures: patents, products in development, and products on the market.).

Figure $2 \mathrm{~b}$ presents the comparable data on venture capital funding (data from Venture Economics). The amount of venture capital funding is less consistent in its effects compared to tied/linked science results. While increasing cumulative amount of venture financing generally increases both patents and products in development, the magnitude of differences is small relative to the tied/linked science effects shown in Figure 2a.

\section{Concentration of Success}

Darby and Zucker (2002) argue that much if not most of technological progress is accounted for by a relatively few firms operating in a relatively few industries undergoing rapid change. We will just touch on examples of concentration here:

- Industry Success Concentration: Top-decile biotech firms account for accounted for 64 percent of the total number of human therapies and vaccines in development (485 as of 1991), 43 percent of all patents, and dominated human therapies and vaccines on the market (82 percent). See Appendix Figure A1. 
- Geographic Concentration: 64 percent of the total products in development are concentrated in the top 5 states (Appendix Table A2); 58 percent of the total products on the market are concentrated in those same 5 states (Appendix Table A3). 


\section{Empirical Results}

\section{The Data}

The Zucker-Darby star-scientists/articles database has been a powerful tool for exploring the co-evolution of life sciences and biotechnology. However, that methodology involves an expenditure of resources justifiable only for pioneering academic efforts or sophisticated financial institutions. As the ISI databases are increasingly available, the extent to which electronic bibliometry can substitute for hand coding and specialized technical knowledge is a question of practical importance to both academic researchers and industry practitioners.

Here we use the basic tool of co-publishing between academic and firm scientists as a detector of joint research and (often two-way) university-industry technology transfer. The Institute of Scientific Information (ISI, 2000) U.S. University Science Indicators database on CD-ROM has extensive information on all the scientific articles with at least one author at any of the top-112 U.S. research universities.

Table 2 defines all the variables used in the empirical estimates and provides summary sample statistics for each. As in Zucker, Darby, and Armstrong (1998), we classify each article in GenBank of which a star scientist is an author relative to each firm as affiliated with the firm, as linked to the firm if the star is unaffiliated but writing with the firm's employees, and otherwise as untied to the firm. Aggregating over all stars and time for each firm gives the first six variables in Table 2. The "local" in local untied articles refers to articles by stars affiliated with universities or research institutes in the firm's functional economic area (metro area plus exurbs as defined by the U.S. Bureau of Economic Analysis). 
We attempted to find all articles written by any employee of each of our biotech firms in the ISI (2000) database; these article also must have at least one top-112 university author to be included. Among these joint articles, we focus on the "core collaborations" in the four central biotech fields catalogued by ISI: biochemistry and biophysics; cell and developmental biology; molecular biology \& genetics; and microbiology. To control for variation in quality of the collaborators, we also collected the number of citations in ISI-indexed journals in the current plus next four years for each article.

The firm characteristics and the last five dependent variables were mostly collected from paper directories and industry studies used by industry participants when looking for suppliers and customers. This methodology is tedious but is one of the few available for analysis of large numbers of privately (as well as publicly) held firms. As described in other papers referenced in Table 2, considerable effort was expended in ensuring that uniform coding procedures were applied to obtain quantitative variables from text records.

The primary exception was the venture funding data obtained by licensing the Venture Economics database and deflating dollar amounts by the GDP deflator. We also had the list of licensees of the UC-Stanford Cohen-Boyer patent as an alternate indicator of the use of recombinant DNA technology. We bought our list of biotech patents from CHI Research, Inc., in 1997. We ensured that the CHI list included all those on U.S. Department of Commerce, Patent and Trademark Office (1993) and appropriate others. Counts of citations to date by other patents were included. 


\section{The Estimates}

In a technology-intensive industry like biotechnology, patents are a crucial measure of success. Patents serve as a measure of output from a firm's "knowledge production function" (Griliches 1990). The patent permits knowledge capture by establishing ownership rights to the invention's commercial rewards until the patent expiration date and even beyond expiration to the extent the firm establishes brand recognition. Patenting success also impacts the firm's ability to raise public equity capital. ${ }^{8}$ Because patent acquisition is key to both financial and non-financial measures of success and citations data are available with which to quality-adjust a firm's patents, the patenting success models are a key testing ground for the electronic version of our star methodology.

Table 3 reports standard poisson regression estimates for panel data on U.S. patenting by U.S. biotech firms. The standard errors are corrected using the procedure of Wooldridge (1991). ${ }^{9}$ Models a and e in Table 3 indicate that simple firm characteristics available for both private and public firms do a good job of explaining patenting. Entrants are generally at a disadvantage, experience helps, and use of the dominant technology (recombinant DNA or genetic engineering) is a positive factor for both quantity and quality of patenting. As always with forward-looking financial variables, the positive effect of the cumulative amount of venture capital investment may confound real R\&D productivity of the investments with forecasting the effects of other, omitted variables.

Firms which have many articles with star scientists also tend to have many articles with top-112 university faculty - indeed nearly all the linked star articles are also included in the top112 core collaborations count of joint faculty-firm articles. If one adds either the star variables used in Zucker, Darby, and Armstrong (1998) or core collaborations and their mean citations (a 
quality measure) as in models $\mathrm{b}$ and $\mathrm{c}$ or $\mathrm{f}$ and $\mathrm{g}$, we see that either set of indicators improves the explanatory power of the models. In the current case of patents and patent citations, the fit is a little better with the new variables than with the star based variables, but we will see below that just the opposite is true for all products and for human therapeutics and vaccines on the market. The failure of local untied star articles to enter significantly positively reaffirms our (1998) result that localized knowledge impacts of universities on industry are associated with market transactions rather than uncompensated spillovers from the ivory tower. The coefficients on cumulative venture capital investment are only mildly reduced by inclusion of either (or both) of the star or top-112 based measures of the firm's science base. This suggests that venture capitalists in the 1980s were not much discriminating among biotech firms on the basis of scientific depth, so that we obtain independent effects on research productivity of both intellectual and financial capital. The significance of the knowable science-base information implies that the capital markets were not fully incorporating it in allocating capital.

Models $\mathrm{d}$ and $\mathrm{h}$ in Table 3 experiment with adding both sets of science indicators at once. Since linked star articles are generally included in the top-112 core collaboration counts, the coefficient on linked articles measures the additional impact of stars on firm research output over and above that of the "average" joint authorship with a professor from a top-112 university. The coefficients for all core collaborations and their mean citations as well as this additional star impact are positive and significant for patents and patent citations. The negative coefficient on affiliated star scientists in these full regressions appears to reflect the special circumstances of one or two firms which have the bulk of affiliated articles.

Unfortunately, the smaller samples for the cross section results in Tables 4,5 , and 6 comparable patent cross-sections are in the appendix available on request - seem more 
confounded by the near multicollinearity of the science variables observed cumulatively up to 1990: For the full models $\mathrm{d}$ and $\mathrm{h}$, where both the star and top-112 article faculty-firm coefficients are significant they have opposite signs. We would prefer panel estimates for products in development and on the market and employment also, but each observation is very costly to obtain from old paper directories for these predominantly private start-up firms. As with the patent panels, we get generally significantly positive coefficients for linked and affiliated star articles (models $\mathrm{b}$ and $\mathrm{f}$ in Tables $4,5,6$ ) or for top-112 core collaboration articles and their mean citations. Employment is the one dependent variable without many zeroes; so in Table 6 we estimate the log of 1994 employment in accord with Gibrat's Law (Sutton, 1997).

In summary, the empirical work strongly supports the central message that universityfirm technology transfer for breakthrough discoveries generally involves detectable joint research between top professors and firms which they own or are compensated by. We have shown that our electronic bibliometry provides good but imperfect substitutes for the more costly to obtain and difficult to operationalize star measures. In particular, in large samples where we can obtain separable impacts, star linkages appear to have a significantly larger effect on firm research productivity than the average article written jointly by top research university professors and firm employees. 


\section{Conclusions}

Breakthrough discoveries in gene splicing set off a revolution in bioscience and created the biotechnology industry. These discoveries set the stage, then, for increased opportunity and increased incentives to enter. But significant natural barriers to the communication of new knowledge often exist. New knowledge tends to be developed in tacit form and requires resources to codify. New codes and formula to describe discoveries develop slowly-with insufficient incentives if value is low and too many competing opportunities if the value is high. Hence new knowledge tends to remain uncodified, difficult to obtain except through hands-on learning at the lab bench, and hence naturally excludable and appropriable. Our basic argument is that knowledge close to breakthrough discoveries needs to be transformed into words, codes and/or formula before it can be easily transferred.

Difficulties inherent to the transfer of tacit knowledge lead to joint research: Team production allows more knowledge capture of tacit, complex discoveries by firm scientists. A robust detector of tacit knowledge capture by the firm (and strong predictor of firm success) is the number of research articles written jointly by scientists working at a firm and the discovering, "star" scientists, nearly all working at top universities. For firms to commercialize new discoveries, there must be sufficient knowledge capture by the firm to offset sunk commercial development costs.

We find the results reported in Zucker, Darby and Armstrong (1998) to be replicated to a major extent in the whole U.S. The principle finding in our earlier paper, covering only California firms, was that research collaborations between firm scientists and university star scientists (the ties) had a robust significant positive effect on firm performance. The local pool of bioscience knowledge generated by nearby but non-collaborating scientists had no positive 
effect, providing further evidence for embodied technology transfer through markets rather than "knowledge spillovers." But this paper is not simply a replication and scale-up.

In this paper we add a generalized form of our star measure: the collaborative research articles between firm scientists and top U.S. university scientists. In panel analyses, firms whose scientists collaborate with stars and/or top 112 U.S. university scientists have more patents and more highly cited patents. Further, star articles have an incremental positive effect above top112 university scientists' articles on the number and quality of patents. Our cross-sectional analyses of products and employment show a generally similar pattern of positive effects on firms' success of collaborations with stars or top university scientists, but the incremental effects are less systematic. This non-robustness appears to be due to multicollinearity. As predicted, untied star articles are either non-significant or oscillate between significant positive and negative effects. Venture capital funding amounts were always significant, and usually positive.

The overall importance of ties, compared to lack of significance or instability of untied star effects, suggests that working jointly at the lab bench is a crucial transfer mechanism when knowledge has an important or large tacit component. Further, our findings suggest that, as we predicted, tacit knowledge is embodied in individual, discovering scientists. Telephone interviews conducted by Jeff Armstrong of university star scientists revealed their relationships with firms were governed by tight contractual arrangements, academic scientists typically being "vertically integrated" into the firm in the sense of receiving equity compensation and being bound by exclusivity agreements. This evidence that star scientists were either fully employed by firms or were governed in their relationships with firms by explicit contracts supported our conclusion that firm success was not the result of a general knowledge "spillover" from universities to firms but due to star scientists taking charge of their discoveries. 


\section{References}

Bioscan. 1989-1998. Volumes 3-12.

Cohen, S., A. Chang, H. Boyer, R. Helling. 1973. Construction of biologically functional bacterial plasmids in vitro. Proc. Nat. Acad. Sci. 70(11) 3240-3244.

Darby, M. R., L. G. Zucker. 2001. Change or die: the adoption of biotechnology in the Japanese and U.S. pharmaceutical industries. Research on Technological Innovation, Management, and Policy 7 85-125.

Darby, M. R., L. G. Zucker. 2002. Growing by leaps and inches: creative destruction and the Crusonia plant. Econ. Inq. $\mathbf{4 0}$ in press.

Darby, M. R., L. G. Zucker, I. I. Welch. 2001. Going public when you can in biotechnology. working paper, UCLA Anderson School, April.

Demsetz, H. 1995. Agency and nonagency explanations of the firm's organization. The Economics of the Business Firm: Seven Critical Commentaries, Cambridge University Press, Cambridge, U.K.

Di Gregorio, D., S. Shane. 2000. Why do some universities generate more start-ups than others? working paper, University of New Mexico and University of Maryland, November.

GenBank. 1990. Release 65.0, machine readable database. IntelliGentics, Inc., Palo Alto, CA.

Griliches, Z. 1990. Patent statistics as economic indicators: a survey. J. Econ. Lit. 28(4) 1661-1707.

Harberger, A. C. 1998. A vision of the growth process. Amer. Econ. Rev. 88(1) 1-32.

Institute of Scientific Information (ISI). 2000. U.S. University Science Indicators. machinereadable database on CD-ROM. Institute of Scientific Information, Philadelphia, PA.

Jaffe, A. B. 1986. Technological opportunity and spillovers of R \& D: evidence from firms' patents, profits, and market value," Amer. Econ. Rev. 76(5) 984-1001. 
Jaffe, A. B. 1989. Real effects of academic research. Amer. Econ. Rev. 79(5) 957-970.

Jensen, R., M. Thursby. 2001. Proofs and prototypes for sale: the tale of university licensing. Amer. Econ. Rev. 91(1) 240-259.

Klevorick, A. K., R. C. Levin, R. R. Nelson, S. G. Winter. 1995. On the sources and significance of interindustry differences in technological opportunities. Res. Policy. 24(2) 185-205.

Kornhauser, W. 1962. Scientists in Industry: Conflict and Accommodation. University of California Press, Berkeley, CA.

Lee, K. B., Jr., G. S. Burrill. 1995. Biotech 95: Reform, Restructure, Renewal. Ernst \& Young, San Francisco, CA.

Nelson, R. R. 1959. The economics of invention: a survey of the literature. J. Bus. 32(2) 101-127.

Nelson, R. R., S. G. Winter. 1982. An Evolutionary Theory of Economic Change. Harvard University Press, Cambridge, MA.

Pisano, G. P., R. M. J. Bohmer, A. C. Edmondson. 2001. Organizational differences in rates of learning: evidence from the adoption of minimally invasive cardiac surgery," Management Sci. 47(6) 752-768.

Polanyi, M. 1974. Personal Knowledge: Towards a Post-Critical Philosophy. University of Chicago Press, Chicago, IL.

Schutz, A. 1962. On multiple realities. Collected Papers 1 207-259. Martinus Nijhoff, The Hague, The Netherlands.

Schutz, A. 1970. Reflections on the Problem of Relevance. Yale University Press, New Haven, $\mathrm{CN}$.

Scott, W. R., S. M. Dornbusch, B. C. Busching, J. D. Laing. 1967. Organizational evaluation and authority. Admin. Sci. Quart. 12 93-117. 
Stephan, P. E., S. S. Everhart. 1998. The changing rewards to science: the case of biotechnology. Small Bus. Econ. 10(2) 141-151.

Stigler, G. J. 1961. The economics of information J. Polit. Econ. 69(3) 213-225.

Sutton, J. 1997. Gibrat's legacy. J. Econ. Lit. 35(1) 40-59.

Thursby, J. G., Marie Thursby. 2000. Who is selling the ivory tower? sources of growth in university licensing. Conference on Technology Transfer and University Entrepreneurship, Georgia Institute of Technology, Atlanta, GA.

Torero, M. 1998. Analyzing the spillover mechanism on the semiconductor industry in the silicon valley and route 128. Essays on Diffusion of Technical Change, unpublished Ph.D. dissertation, UCLA Economics Department.

Torero, M., M. R. Darby, L. G. Zucker. 2001. The importance of intellectual human capital in the birth of the semiconductor industry. working paper, UCLA Anderson School, January.

U.S. Department of Commerce, Patent and Trademark Office. 1993. Patent Technology Set: Genetic Engineering. machine readable data base on CD-ROM. U.S. Department of Commerce, Office of Information Systems, Washington, DC.

Wooldridge, J. M. 1991. On the application of robust, regression-based diagnostics to models of conditional means and conditional variances. J. Econometrics 47 5-46.

Yarkin, C. 2000. Assessing the role of the University of California in the state's biotechnology economy. The Economic and Social Dynamics of Biotechnology. Kluwer Academic Publishers, Boston, MA. 
Zucker, L. G., M. R. Darby. 2001. Capturing technological opportunity via Japan's star scientists: evidence from Japanese firms' biotech patents and products. J. Technology Transfer. 26(1/2) 37-58.

Zucker, L. G., M. R. Darby, J. S. Armstrong. 1998. Geographically localized knowledge: spillovers or markets?" Econ. Inq. 36(1) 65-86.

Zucker, L. G., M. R. Darby, M. B. Brewer. 1998. Intellectual human capital and the birth of U.S. biotechnology enterprises. Amer. Econ. Rev. 88(1) 290-306.

Zucker, L. G., M. R. Darby, M. Torero. 2000. Determinants of embodied technology transfer from stars to firms, working paper, UCLA Anderson School.

Zucker, L. G., M. R. Darby, M. Torero. 2001. Labor mobility from academe to commerce. $J$. Labor Econ. $\mathbf{2 0}$ in press. 


\section{Footnotes}

${ }^{1}$ Most commonly, there are multiple virtually localized markets organized around competing perspectives or models employed within the sub-specialty. There is also geographic localization within the professions, with advantages to universities or cities with a "critical mass" of scientists who can interact. Thus, UCSF with its critical mass of molecular biologists and related sciences, and nearby strong universities, was "ripe" for a breakthrough.

${ }^{2}$ Note that when multiple teams are racing for a "ripe" discovery and publish their results almost simultaneously, we have much more rapid confirmation/validation of the discovery which promotes faster learning by others. Gina Durante, graduate student at the Anderson School at UCLA, suggested this point.

3 The top 112 universities are defined in terms of rank order on Federal research funding received. The top 112 are defined by the Institute for Scientific Information and the data were purchased from them.

${ }^{4}$ In 1994, Jeff Armstrong conducted a telephone survey of randomly selected linked stars in California and found that most possess a significant equity or founding interest in the firm.

${ }^{5}$ The prospectuses were obtained from Thomson Financial Services. The ten companies in the table were the top biotechnology firms in 1994 as reported by Lee and Burrill (1995, p.16).

${ }^{6}$ Due to human subjects' restrictions, we cannot reveal the identity of the star scientists. The following scientists may or may not be included in our list of U.S. stars.

${ }^{7}$ It is interesting that Genentech-with the largest number of star scientists of any firmappeared to avoid mentioning stars on its prospectus resume unless the star had a formal corporate position. The one leading scientist who was listed on the prospectus was Dr. Boyer, 
who made it a policy never to publish a genetic-sequence discovery article as or with a Genentech employee.

${ }^{8}$ See Darby, Zucker and Welch (2001).

9 The significance of key variables in these regressions is generally not sensitive to the Wooldridge correction, but to achieve an estimate of the variance-covariance matrix that is not restricted by first-moment parameter estimates, we apply the Wooldrige method as we did in the California study. An alternative would be to implement a binomial specification, but as explained in Wooldridge (1991), this procedure may bias both first and second moment estimates, whereas the Poisson process potentially biases only the second moment parameters. 
Table 1 The Ten Most Highly Valued Biotechnology Firms in 1994: Leading Academic Scientists Appear on Their IPO Prospectus and as Joint Authors

\begin{tabular}{|c|c|c|c|c|c|}
\hline \multirow[t]{2}{*}{ Company $^{a}$} & \multirow[t]{2}{*}{ IPO Date } & \multicolumn{2}{|c|}{ Star Scientists } & \multicolumn{2}{|c|}{ Top-112 University Professors } \\
\hline & & $\begin{array}{l}\text { Listed on the } \\
\text { Prospectus }\end{array}$ & $\begin{array}{l}\text { Linked } \\
\text { Articles }\end{array}$ & $\begin{array}{l}\text { Listed on the } \\
\text { Prospectus }\end{array}$ & $\begin{array}{c}\text { Core } \\
\text { Collaborations }\end{array}$ \\
\hline Genentech, Inc. & October 1980 & & $\checkmark$ & $\checkmark$ & $\checkmark$ \\
\hline Centocor, Inc. & June 1982 & $\checkmark$ & $\boldsymbol{V}$ & $\checkmark$ & $\checkmark$ \\
\hline Chiron Corporation & August 1983 & $\checkmark$ & $\boldsymbol{V}$ & $\checkmark$ & $\checkmark$ \\
\hline Biogen N.V. & March 1983 & $\checkmark$ & $\boldsymbol{V}$ & $\checkmark$ & $\checkmark$ \\
\hline Amgen, Inc. & June 1983 & $\checkmark$ & $\checkmark$ & $\checkmark$ & $\boldsymbol{V}$ \\
\hline Immunex Corp. & July 1983 & & $\boldsymbol{V}$ & $\checkmark$ & $\boldsymbol{V}$ \\
\hline ALZA Corp. ${ }^{c}$ & December 1985 & & & & \\
\hline Genzyme Corp. $^{\mathrm{d}}$ & June 1986 & & & $\checkmark$ & $\checkmark$ \\
\hline $\begin{array}{l}\text { Genetics Institute, } \\
\text { Inc. }\end{array}$ & May 1986 & & $\checkmark$ & $\checkmark$ & $\boldsymbol{V}$ \\
\hline $\begin{array}{l}\text { IDEXX Laboratories, } \\
\text { Inc. }\end{array}$ & June 1991 & & & & $\checkmark$ \\
\hline
\end{tabular}

Notes:

${ }^{a}$ Top 10 biotechnology firms in terms of market value as identified in Lee and Burrill's (1995) ninth annual industry report for Ernst \& Young.

${ }^{b}$ Listed on the IPO prospectus as an executive, director, or member of the company's scientific advisory board.

${ }^{c}$ ALZA Corp. was founded in 1968 before genetic engineering and has successfully pursued a specialized niche R\&D strategy by concentrating on developing sophisticated drug delivery systems rather than drug discovery.

${ }^{\mathrm{d}}$ Genzyme Corp. had an extensive long-term contractual relationship with BioInformation Associates (BIA). BIA was owned by a group of eight academic scientists: George Whitesides at Harvard and seven MIT professors: Charles Cooney (also appointed as a Genzyme Director), Harvey Lodish, Chokyun Rha, William Roush, Anthony Sinskey, Graham Walker, and Christopher Walsh. 
Table 2 Definitions and Sample Statistics for Variables

\begin{tabular}{|c|c|c|c|c|c|c|}
\hline Variables & Definitions & Mean & S.D. & Min & Max & $\mathbf{N}$ \\
\hline \multicolumn{7}{|l|}{ Independent Variables } \\
\hline $\begin{array}{l}\text { Cumulative Star Authorships } \\
\text { of: }\end{array}$ & Articles to date written by a star scientist: & & & & & \\
\hline Local untied articles & not firm-affiliated/not linked to this firm & 120.0 & 125.3 & 0 & 387 & 3152 \\
\hline Affiliated articles & affiliated with this firm & 0.40 & 6.25 & 0 & 139 & 3152 \\
\hline All linked articles & not firm-affiliated/with this firm's emp. & 0.19 & 1.39 & 0 & 20 & 3152 \\
\hline Star Authorships of: & Articles to 1990 written by star scientist: & & & & & \\
\hline Local untied articles & not firm-affiliated/not linked to this firm & 164.5 & 149.5 & 0 & 382 & 342 \\
\hline Affiliated articles & affiliated with this firm & 0.50 & 7.596 & 0 & 139 & 342 \\
\hline All linked articles & not firm-affiliated/with this firm's emp. & 0.281 & 1.732 & 0 & 20 & 342 \\
\hline $\begin{array}{l}\text { Cumulative Top-112 } \\
\text { University Authorships: }\end{array}$ & $\begin{array}{l}\text { For articles to date with any author(s) at } \\
\text { an ISI-defined top-112 university: }\end{array}$ & & & & & \\
\hline All core collaborations & number with this firm's employee(s) & 1.57 & 10.36 & 0 & 271 & 3152 \\
\hline Citations to articles & mean citations in 5 years to above & 5.45 & 18.24 & 0 & 254 & 3152 \\
\hline $\begin{array}{l}\text { Top-112 University } \\
\text { Authorships: }\end{array}$ & $\begin{array}{l}\text { For articles through } 1990 \text { with any au- } \\
\text { thor(s) at an ISI-defined top-112 univ.: }\end{array}$ & & & & & \\
\hline All core collaborations & number with any this firm's employees & 5.918 & 26.27 & 0 & 337 & 342 \\
\hline Citations to articles & mean citations in 5 years to above & 10.23 & 24.87 & 0 & 225 & 342 \\
\hline \multicolumn{7}{|l|}{ Firm Characteristics: } \\
\hline NBF indicator & 1 if entrant firm; otherwise 0 & 0.746 & 0.436 & 0 & 1 & 342 \\
\hline Years in biotech & Year +1 - year firm began using biotech & 7.216 & 3.117 & 1 & 14 & 342 \\
\hline Recombinant DNA indicator & 1 if firm uses recomb. DNA; otherwise 0 & 0.479 & 0.500 & 0 & 1 & 342 \\
\hline $\begin{array}{l}\text { Cumulative venture capital } \\
\text { funding }\end{array}$ & $\begin{array}{l}\text { Amount of venture capital received by } \\
\text { this firm to date in } 100,000 \text { s of } 1984 \$ \mathrm{~s}\end{array}$ & 24.26 & 65.65 & 0 & 899.5 & 3152 \\
\hline $\begin{array}{l}\text { Cumulative venture capital } \\
\text { funding as of } 1990\end{array}$ & $\begin{array}{l}\text { Amount of venture capital received by } \\
\text { this firm to } 1990 \text { in } 100,000 \text { s of } 1984 \$ \mathrm{~s}\end{array}$ & 42.92 & 94.49 & 0 & 899.5 & 342 \\
\hline \multicolumn{7}{|l|}{ Dependent Variables } \\
\hline Cumulative patents granted & $\begin{array}{l}\text { Number of biotech patents applied for to } \\
\text { date and assigned at issue to this firm }\end{array}$ & 0.97 & 4.56 & 0 & 96 & 3152 \\
\hline $\begin{array}{l}\text { Cumulative patents granted } \\
\text { as of } 1991\end{array}$ & $\begin{array}{l}\text { No. of biotech patents applied for by end } \\
\text { of } 1991 \text { and assigned at issue to this firm }\end{array}$ & 2.652 & 9.337 & 0 & 120 & 342 \\
\hline $\begin{array}{l}\text { Cumulative citation-weighted } \\
\text { patents granted }\end{array}$ & $\begin{array}{l}\text { Number of citations received up to year } \\
1997 \text { to biotech patents applied for to date } \\
\text { and assigned at issue to this firm }\end{array}$ & 8.881 & 41.69 & 0 & 820 & 3152 \\
\hline $\begin{array}{l}\text { Cumulative citation-weighted } \\
\text { patents granted as of } 1991\end{array}$ & $\begin{array}{l}\text { No. of citations received up to year } 1997 \\
\text { to biotech patents applied for through } \\
1991 \text { and assigned at issue to this firm }\end{array}$ & 19.68 & 70.63 & 0 & 820 & 342 \\
\hline $\begin{array}{l}\text { Total products in } \\
\text { development }\end{array}$ & $\begin{array}{l}\text { Count of Total Products in Development } \\
\text { in } 1990 \text { Bioscan }\end{array}$ & 1.895 & 3.231 & 0 & 22 & 342 \\
\hline $\begin{array}{l}\text { Total human therapies and } \\
\text { vaccines in development }\end{array}$ & $\begin{array}{l}\text { Count of Human Therapies \& Vaccines in } \\
\text { Development in } 1990 \text { Bioscan }\end{array}$ & 1.418 & 3.031 & 0 & 22 & 342 \\
\hline Total products on the market & $\begin{array}{l}\text { Count of Total Products on the Market in } \\
1990 \text { Bioscan }\end{array}$ & 3.781 & 5.326 & 0 & 37 & 342 \\
\hline $\begin{array}{l}\text { Total human therapies and } \\
\text { vaccines on the market }\end{array}$ & $\begin{array}{l}\text { Count of Human Therapies \& Vaccines } \\
\text { on the Market in } 1990 \text { Bioscan }\end{array}$ & 0.547 & 1.591 & 0 & 13 & 342 \\
\hline Total employees as of 1994 & Employment reported in 1994 Bioscan & 926.2 & 7983 & 1 & 110,400 & 233 \\
\hline
\end{tabular}

Panel variables $(\mathrm{N}=3152)$ have observations by firm and year; others are observed only once per firm.

Detailed definitions and sources in text and data appendices in NBER Working Papers 4653, 4949, and 6360 (draft versions of Zucker, Darby, and Brewer 1998, Zucker, Darby, and Armstrong 1998, and Zucker and Darby 2001). 


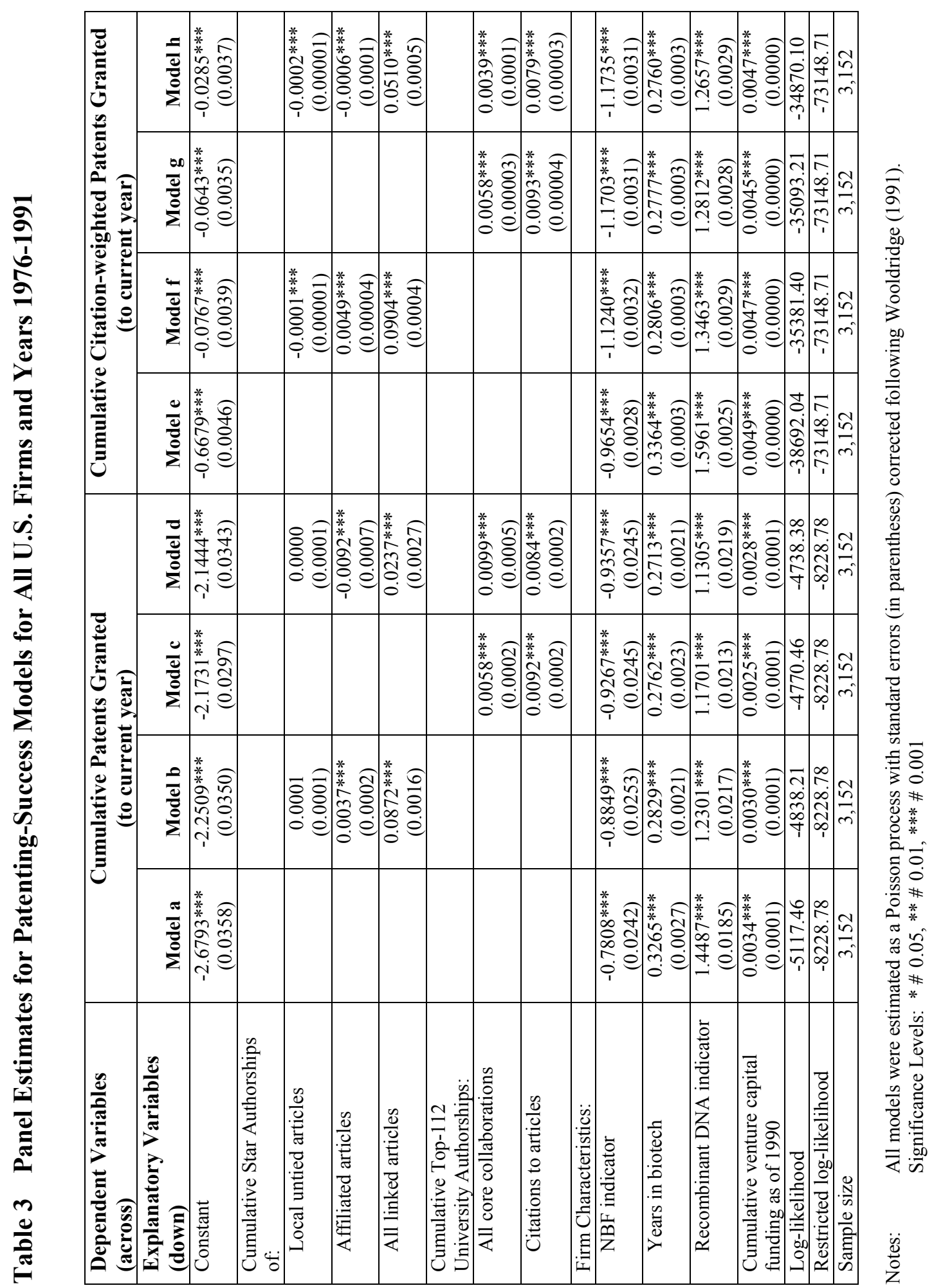




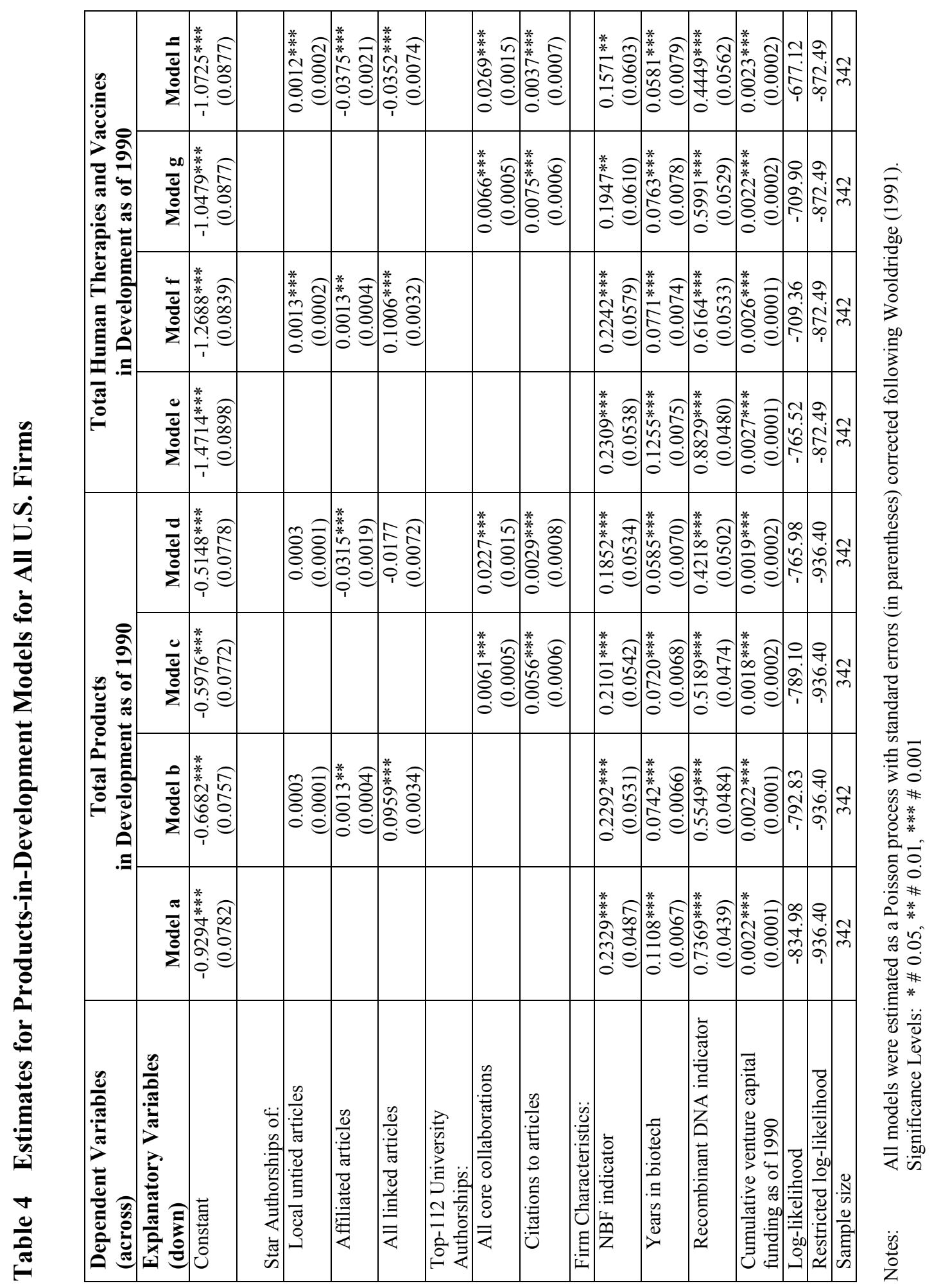

ก 


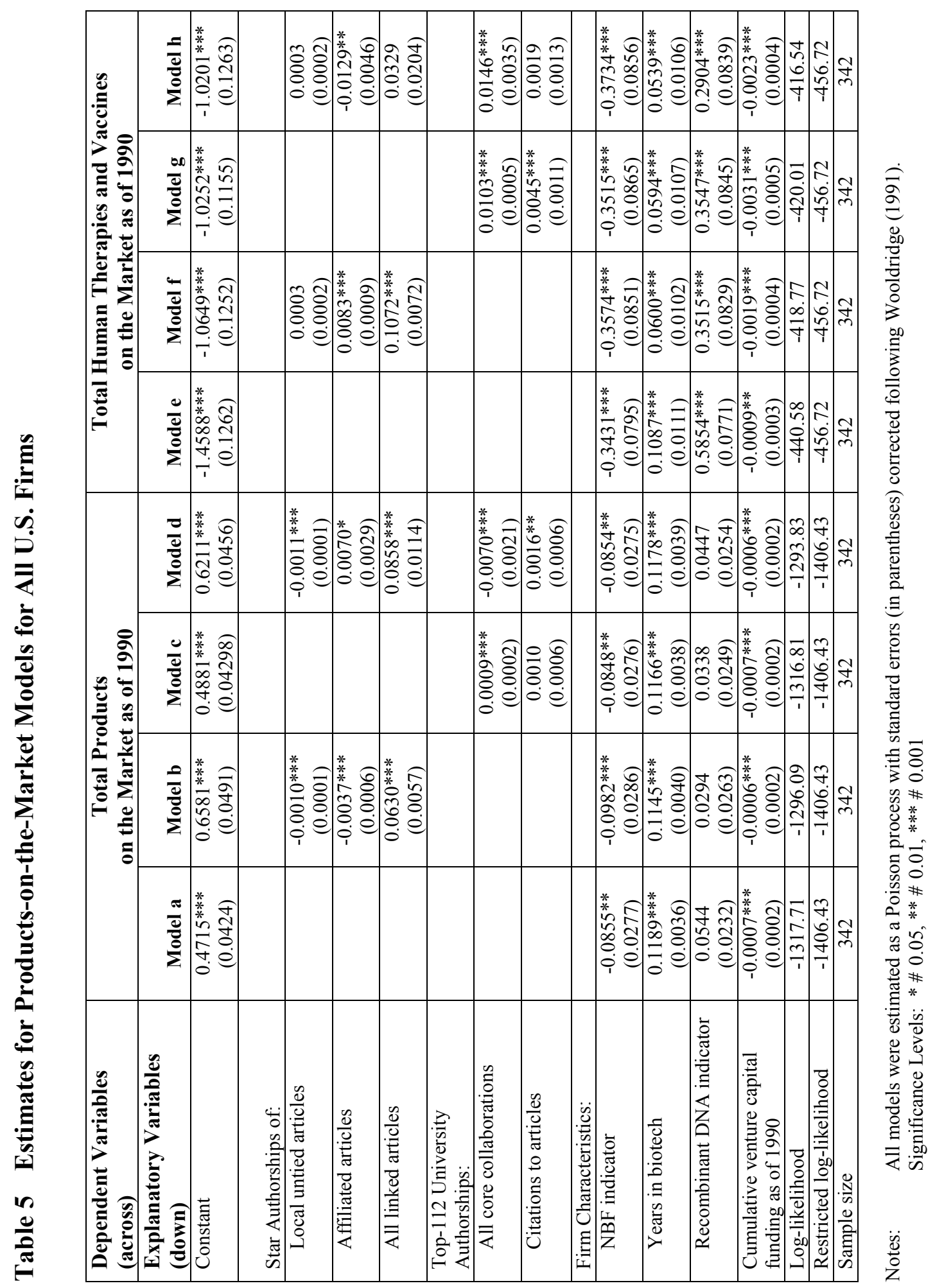


Table 6 OLS Estimates for 1994 Employment for All Reporting U.S. Firms Dependent Variable: Natural Logarithm of Total Employees as of 1994

\begin{tabular}{|l|c|c|c|c|}
\hline $\begin{array}{l}\text { Explanatory Variables } \\
\text { (down) }\end{array}$ & Model a & Model b & Model c & Model d \\
\hline Constant & $\begin{array}{c}4.416^{* * *} \\
(0.3379)\end{array}$ & $\begin{array}{c}4.3516^{* * *} \\
(0.3449)\end{array}$ & $\begin{array}{c}4.6815^{* * *} \\
(0.3338)\end{array}$ & $\begin{array}{c}4.5195^{* * *} \\
(0.3454)\end{array}$ \\
\hline & & & & \\
Star Authorships of: & & & & $0.0014^{*}$ \\
\hline Local untied articles & & $0.0015^{*}$ & & $(0.0007)$ \\
& & 0.0074 & & -0.0236 \\
\hline Affiliated articles & & $(0.0118)$ & & $(0.0191)$ \\
\hline All linked articles & & $0.1201^{*}$ & & -0.0148 \\
& & & & \\
\hline Top-112 university \\
authorships:
\end{tabular}

Notes: $\quad$ Sample size was reduced because of non-reporting for 109 firms.

Standard errors (in parentheses).

Significance Levels: * \#0.05, ** \#0.01, ***\#0.001 

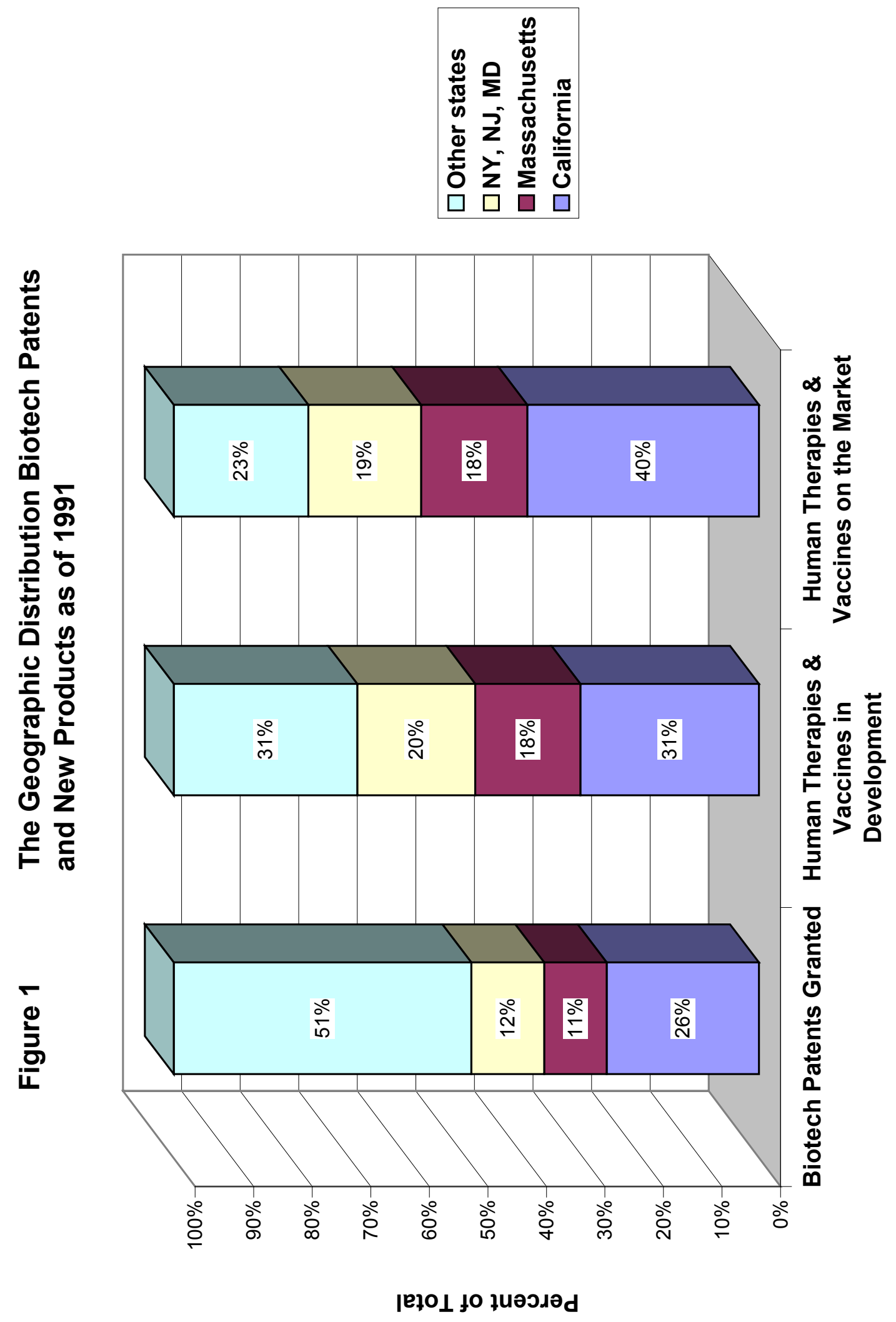
Figure 2a Biotech Firms Are More Successful if Tied to Star Scientists or if Linked to Top-Research-University Faculty

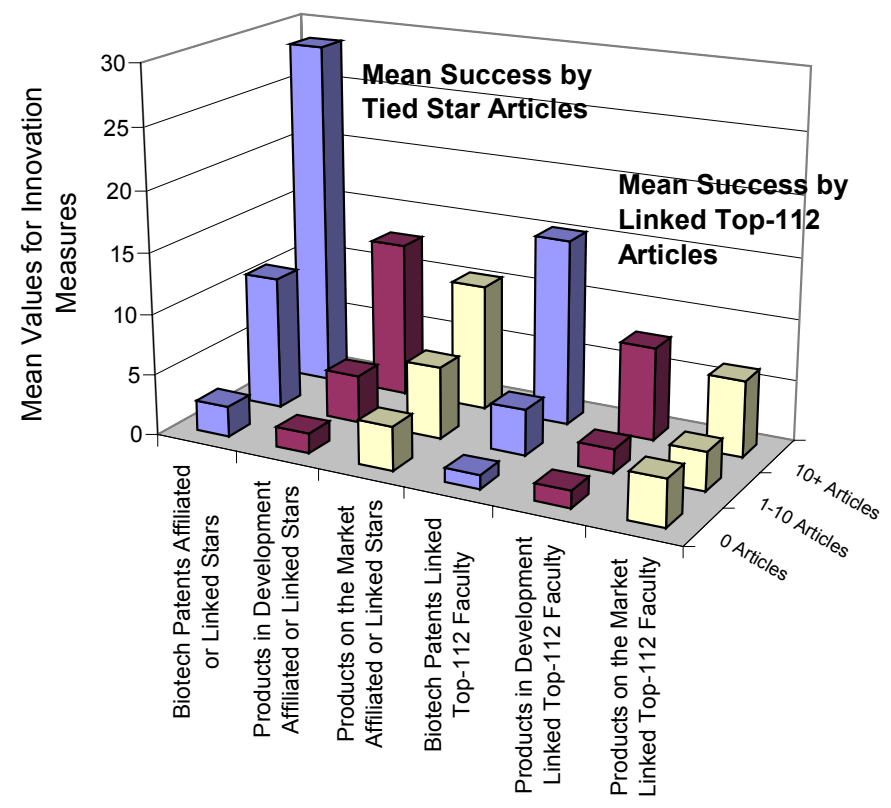

Figure 2b Biotech Firms Are More Successful if Funded by Venture Capitalists

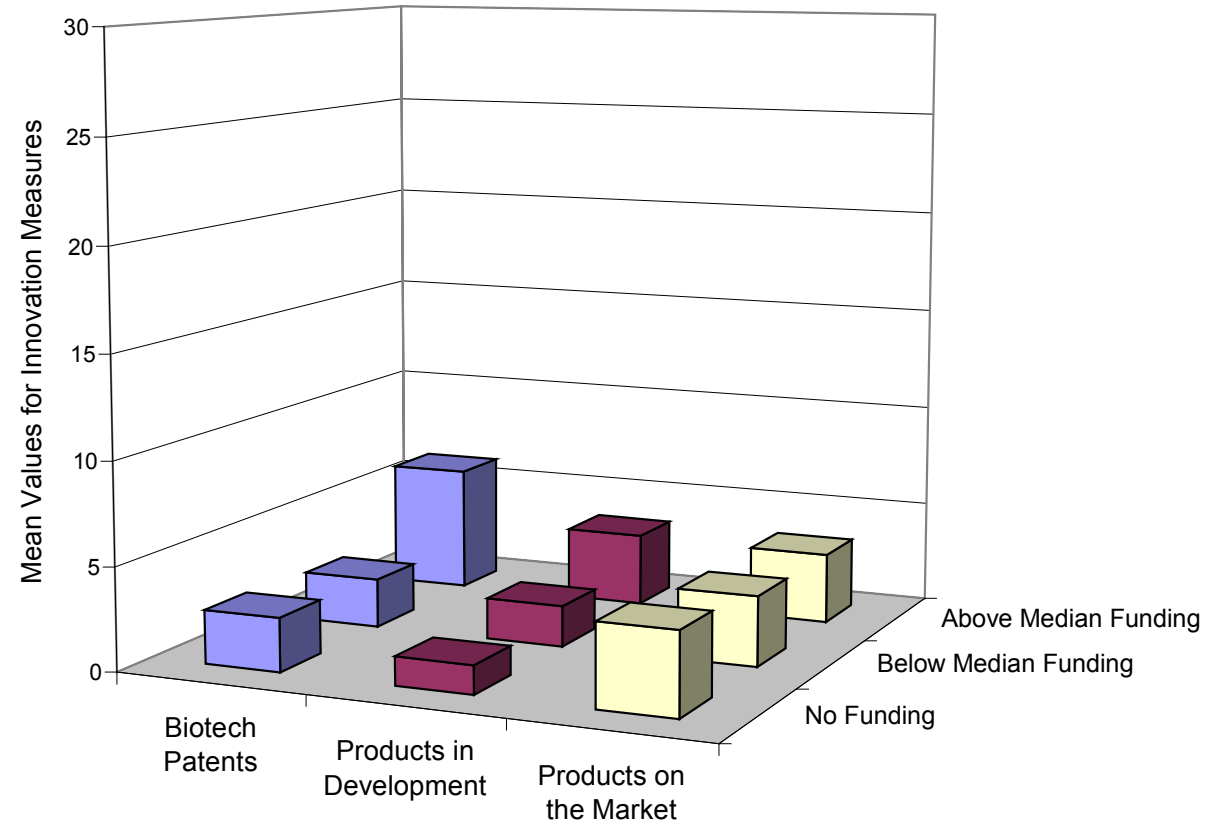




\section{Appendix - Supplementary Analyses}

The tables and figure in this appendix provide supplementary analyses to those in the main text and some additional detail on data used in the empirical analysis. The depth of involvement of top academic scientists in the best biotech firms indicated in Table 1 is corroborated in Appendix Tables A1. Appendix Tables A2 and A3 provide totals by states of the firms in the sample and the 1991 counts of total products, human therapeutics, vaccines, diagnostics, and agricultural products in development and on the market, respectively. Figure A1 shows how concentrated research activity is in the top decile biotech firms.

Appendix Table A4 lists exactly which universities make the ISI's top-112 list based on amount of federal research funding received.

Appendix Table A5 reports the results of running the patent analysis as a cross-section without exploiting the timing aspect of the data. The ability to have both star and top-112 science base indicators in the regression simultaneously appears to be a feature of the fuller analysis and not of the patents per se. 
Appendix Table A1

\section{Leading Academic Scientists Held Key Positions in the Top-10 Biotechnology Firms in 1994}

\begin{tabular}{|c|c|c|}
\hline Position & $\begin{array}{r}\text { Number of Tied } \\
\text { Star Scientists }^{\mathrm{a}}\end{array}$ & $\begin{array}{l}\text { Number of Top-Ten } \\
\text { University Scientists }\end{array}$ \\
\hline Founder/co-founder & 1 & 6 \\
\hline President and CEO & 0 & 2 \\
\hline Vice-President & 0 & 6 \\
\hline Director $^{\mathrm{c}}$ & 2 & 12 \\
\hline Scientific Advisory Board Member ${ }^{\mathrm{d}}$ & 2 & 24 \\
\hline
\end{tabular}

Notes:

${ }^{a}$ Equals the number of tied star scientists holding the position indicated by the row label. The column total may exceed the number of scientists since scientists could hold multiple positions within the firm.

${ }^{\mathrm{b}}$ Equals the number of top-112 university scientists holding the position indicated by the row label. The column total may exceed the number of scientists since scientists could hold multiple positions within the firm.

${ }^{c}$ One tied star scientist was listed as the Board Chair and another was listed as Board Secretary.

${ }^{\mathrm{d}}$ One of the top-112 university scientists was listed as the Scientific Advisory Board Chair. 

Human Therapeutics, Vaccines, Diagnostics and Agricultural

\begin{tabular}{|l|c|c|c|c|c|c|}
\hline \multicolumn{1}{|c|}{ State } & $\begin{array}{c}\text { Total } \\
\text { Products }\end{array}$ & $\begin{array}{c}\text { Thera- } \\
\text { peutics }\end{array}$ & Vaccines & Diagnostics & Agriculture & $\begin{array}{c}\text { Firms in } \\
\text { Sample }\end{array}$ \\
\hline California & 175 & 136 & 12 & 14 & 4 & 96 \\
Massachusetts & 101 & 81 & 6 & 4 & 6 & 39 \\
Maryland & 18 & 9 & 0 & 5 & 3 & 16 \\
New Jersey & 73 & 57 & 1 & 6 & 0 & 27 \\
New York & 46 & 28 & 3 & 12 & 1 & 24 \\
Others & 235 & 133 & 19 & 42 & 7 & 140 \\
& & & & & & \\
\hline Total & 648 & 444 & 41 & 83 & 21 & 342 \\
\hline
\end{tabular}

Source: Bioscan.

Appendix Table A3

Products on the Market by Key State as of 1991: Total Products, Human Therapeutics, Vaccines, Diagnostics and Agricultural

\begin{tabular}{|l|c|c|c|c|c|c|}
\hline \multicolumn{1}{|c|}{ State } & $\begin{array}{c}\text { Total } \\
\text { Products }\end{array}$ & $\begin{array}{c}\text { Thera- } \\
\text { peutics }\end{array}$ & Vaccines & Diagnostics & Agriculture & $\begin{array}{c}\text { Firms in } \\
\text { Sample }\end{array}$ \\
\hline California & 381 & 73 & 1 & 119 & 19 & 96 \\
Massachusetts & 148 & 33 & 1 & 73 & 6 & 39 \\
Maryland & 56 & 6 & 0 & 17 & 1 & 16 \\
New Jersey & 60 & 14 & 0 & 11 & 1 & 27 \\
New York & 104 & 16 & 0 & 59 & 0 & 24 \\
Others & 235 & 37 & 6 & 122 & 24 & 140 \\
\hline Total & 1,296 & 179 & 8 & 401 & 51 & 342 \\
\hline
\end{tabular}

Source: Bioscan. 


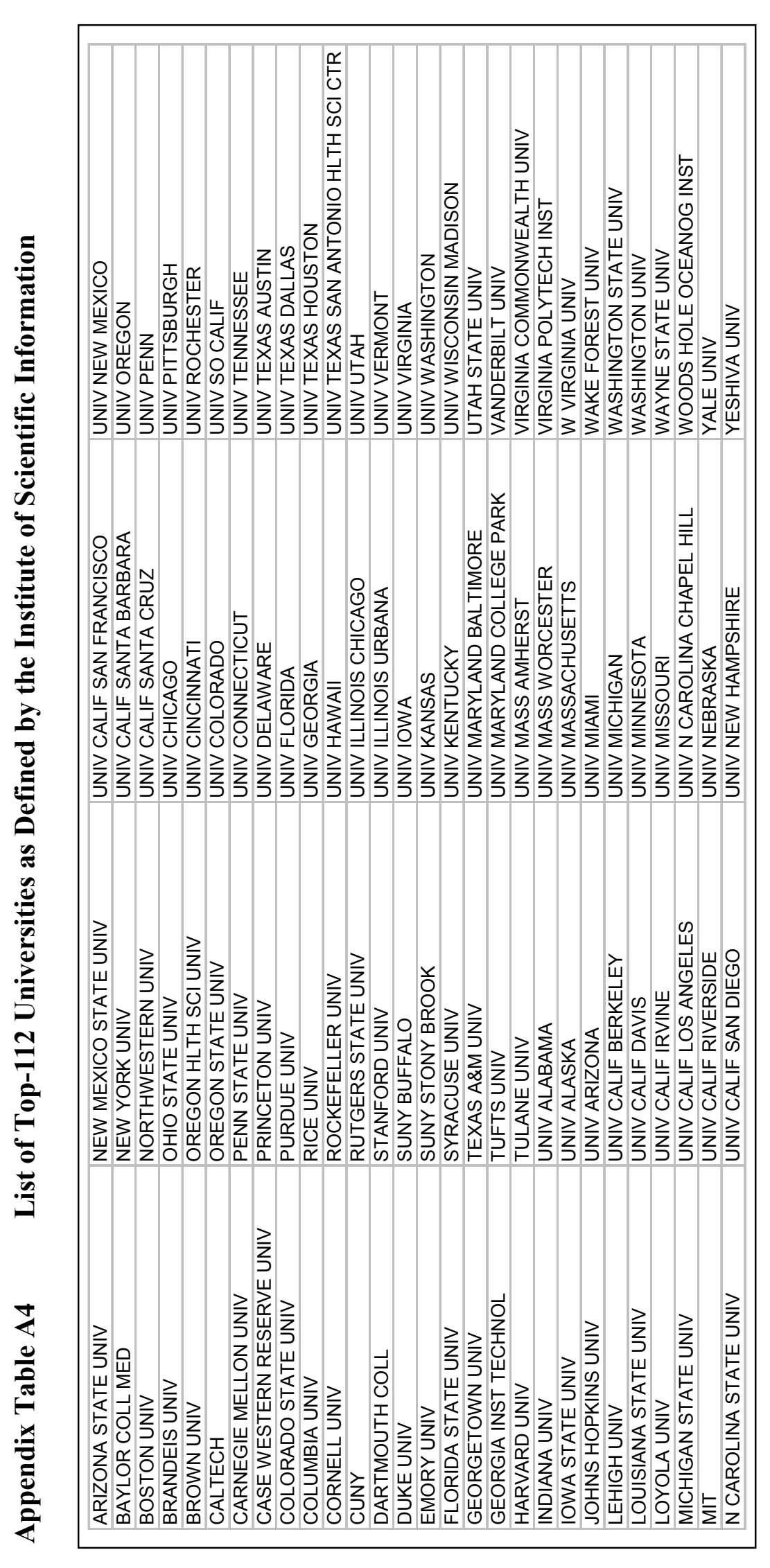

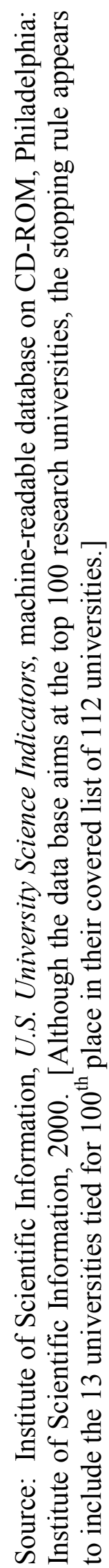




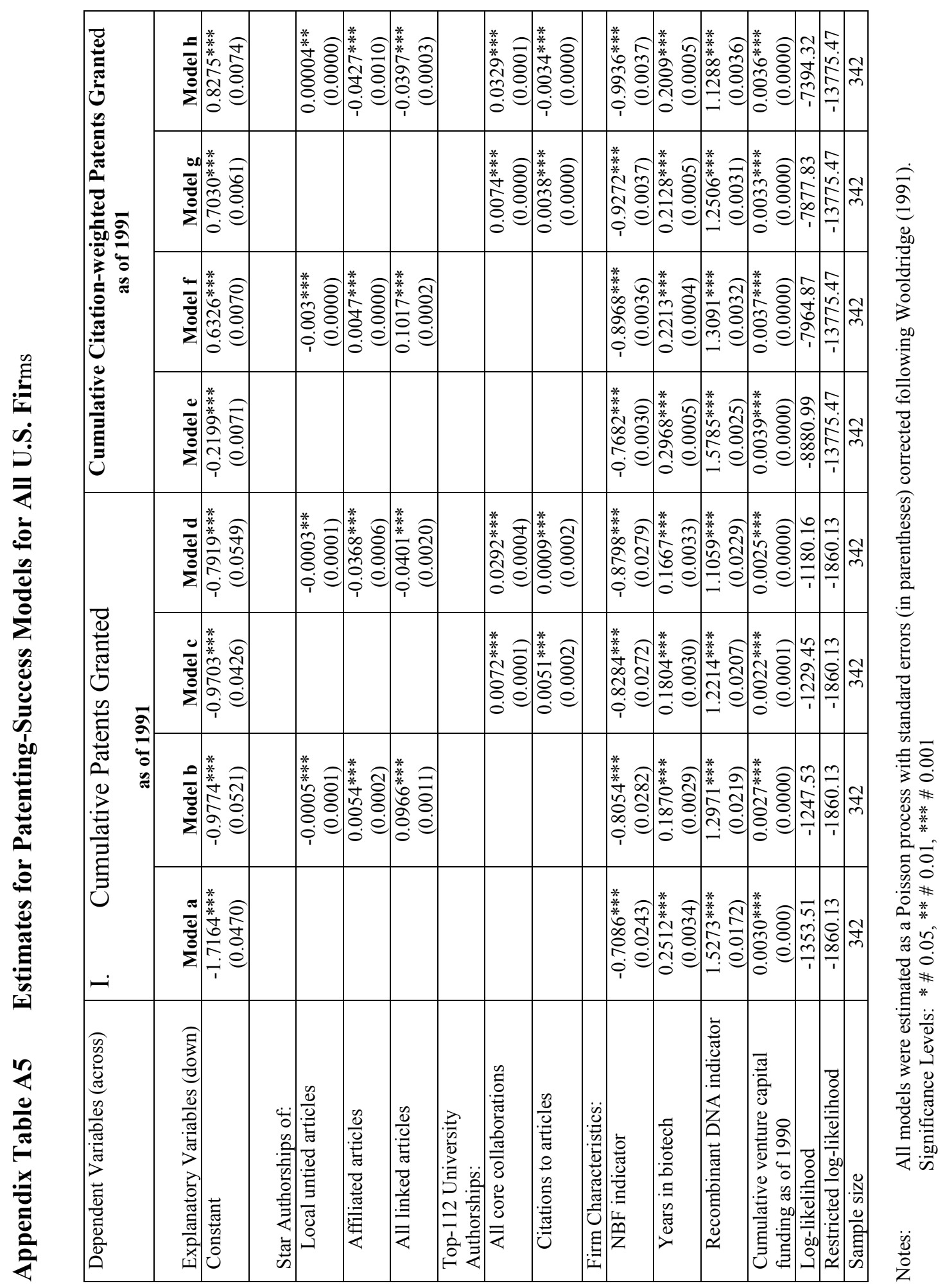



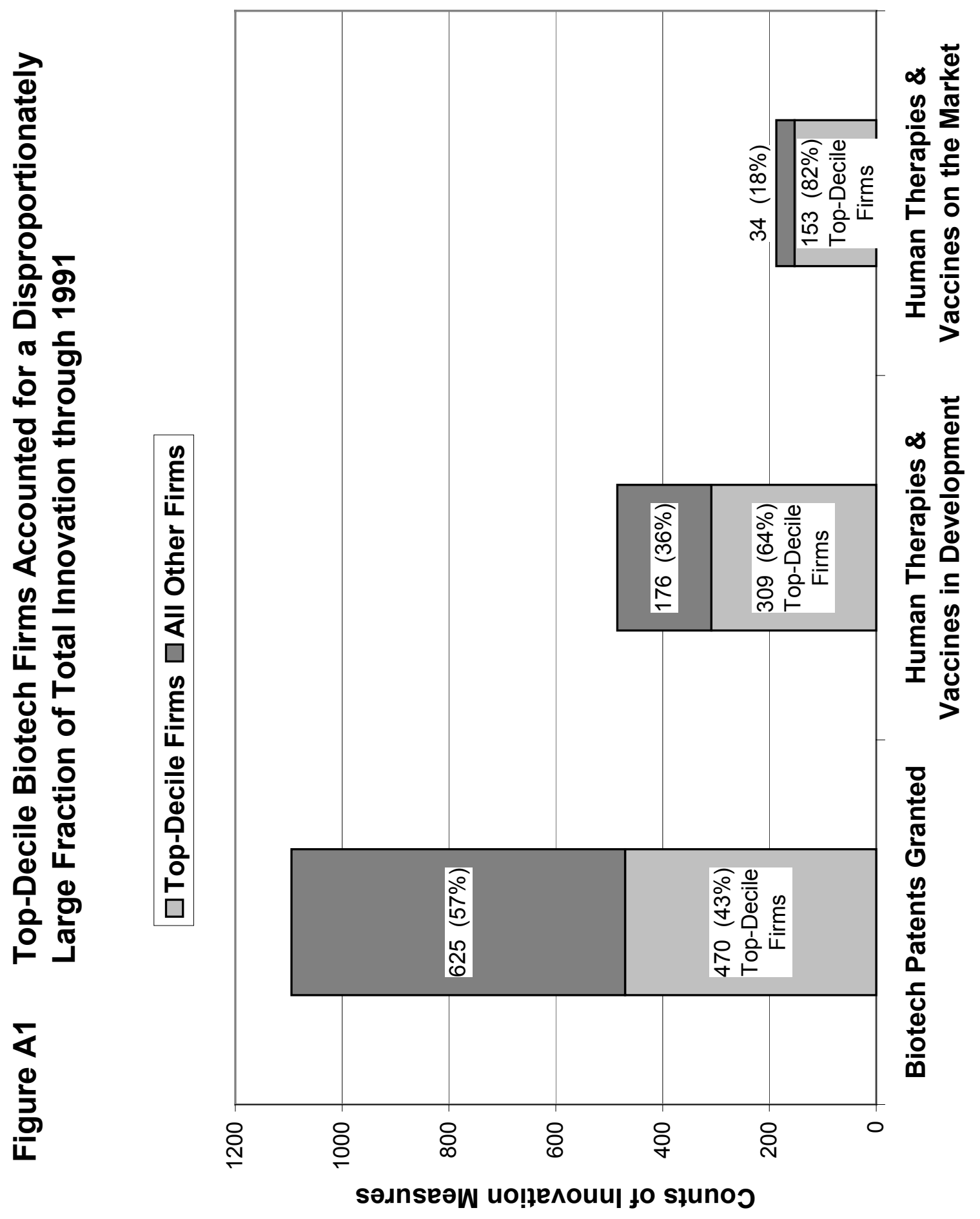